\title{
Analisis Pengaruh Brand Image Trust, Security, Perceived usefulness, Perceived Ease of Use terhadap adoption Intention Fintech di kota Batam
}

\author{
Yandi Suprapto \\ Universitas Internasional Batam \\ yandi.suprapto@uib.ac.id
}

\section{Farida}

Universitas Internasional Batam

fariidaweng@gmail.com

\begin{abstract}
Abstrak
Penelitian ini bertujuan guna mendapati pengaruh brand image, trust, security, perceived usefulness, dan perceived ease of use terhadap adoption intention fintech. Penelitian dijalankan dengan metode survei penyebaran kuesioner kepada 150 responden yang merupakan pengguna layanan fintech di mall Kota Batam dan diuji dengan SPSS versi 25. Penelitian didapati hasil yang menunjukkan brand image dan trust tidak berpengaruh terhadap adoption intention fintech, sedangkan security, perceived usefulness, perceived ease of use berpengaruh positif terhadap intention fintech.
\end{abstract}

Kata Kunci brand image, trust, security, perceived usefulness, perceived ease of use, adoption intention fintech

\section{PENDAHULUAN}

Teknologi informasi pada era sekarang yang perkembangannya semakin memadai dan berperan pada keseharian kita yang tidak dapat diabaikan karena membawa pengaruh langsung dalam aktivitas yang dijalankan. Teknologi memiliki hubungan yang berkaitan dengan keuangan. Indonesia dengan jumlah penduduk yang mencapai 267 juta penduduk yang sudah tidak asing dan sering menggunakan internet sehingga terjadi peningkatan penggunaan internet yang memungkinkan perkembangan financial technology atau fintech di Indonesia (Bappenas, 2019).

Dibanding dengan beberapa negara Asia Tenggara lain, Indonesia memiliki angka adopsi fintech yang relatif tinggi. Di era modern ini, hampir semua yang dilakukan mulai dari transportasi, makan, pembayaran tagihan menggunakan fintech melalui Go-pay, OVO, DANA, dan lain-lain. Dengan adanya fintech mengarahkan sektor keuangan berjalan lebih efisien. 


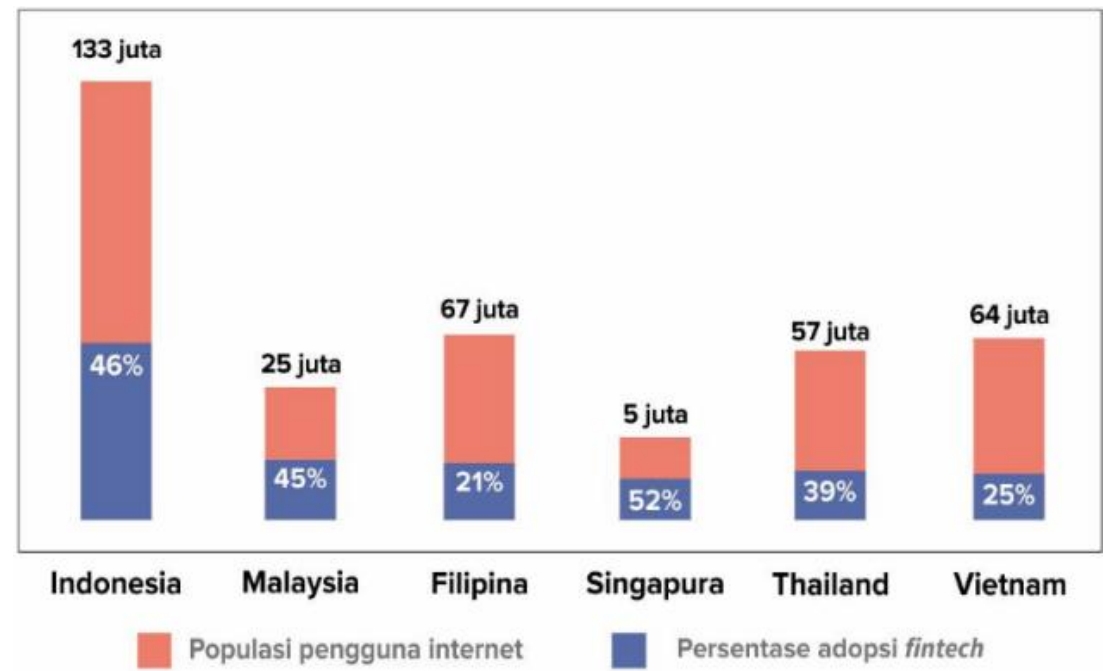

Gambar 1. Jumlah pengguna internet dan estimasi persentase adopsi fintech di sejumlah negara Asia Tenggara tahun 2018. Sumber: (Kurniawan, 2019)

Menurut pendataan yang ada dalam Bank Indonesia, memiliki transaksi sebesar 17,23 Triliun Rupiah dalam transaksi elektronik yang tercatat besar volume transaksi terdiri dari 386,7 juta pada Agustus 2020. Hasil tersebut tentunya tercatat mengalami peningkatan dibandingkan bulan sebelumnya yang hanya tercatat 16,09 Triliun Rupiah dan transaksi yang ada bervolume 381,5 juta (Malik, 2020). Berikut ini tabel pendataan penggunaan fintech pertahun 2020:

Tabel 1. Nilai Transaksi Uang Elektronik 2020

\begin{tabular}{ccc}
\hline No & Bulan & Nominal (triliun) \\
\hline 1 & Januari & 15,87 \\
2 & Februari & 15,17 \\
3 & Maret & 15,03 \\
4 & April & 17,55 \\
5 & Mei & 15,03 \\
6 & Juni & 14,95 \\
7 & Juli & 16,09 \\
8 & Agustus & 17,23 \\
\hline
\end{tabular}

Sumber: (Malik, 2020)

Surat edaran yang berasal dari Jendral Kemendagri Republik Indonesia menyatakan tanggal 17 April 2017 menyampaikan agar segera diimplementasi transaksi non-cash dalam setiap transaksi yang dilakukan selambat-lambatnya pada Januari 2018. Batam termasuk salah satu kota yang menjalankan kebijakan tersebut karena hanya beberapa daerah saja yang menjalankannya (Haluan, 2019). Hasil pengguna fintech dalam melakukan transaksi non-cash masih belum merata, dikarenakan masih belum semua pedagang menerima transaksi non-cash dan masyarakat lebih suka membayar dengan cash dibanding non-cash karena sudah terbiasa dan lebih aman (Parastiti et al., 2015).

Hingga saat ini penggunaan fintech patut mendapat perhatian dikarenakan $90 \%$ dari responden survei dinyatakan menggunakan fintech, tercatat $73 \%$ responden menggunakan OVO, 71\% memiliki Go-pay, sedangkan pengguna DANA 1\% (Rahadian, 2019). Davis et al. (1989) telah mengemukakan bahwa konsep TAM memiliki teori yang 
menjelaskan manfaat penggunaan dan kemudahan penggunaan sebagai penentu penerimaan dari pengguna suatu teknologi.

Berdasarkan isu-isu yang ada sehingga penulis merasa terdorong untuk meneliti tiap faktor yang memberikan pengaruh niat adopsi fintech di Kota Batam. Faktor-faktor yang diteliti meliputi Brand Image, Trust, Security, Perceived Usefulness, Perceived Ease of Use terhadap Adoption Intention Fintech. Penelitian yang dilakukan bertujuan guna mengetahui korelasi dari tiap variabel yang diuji.

\section{LANDASAN TEORI}

\section{Brand Image}

Hu et al. (2019) menyatakan brand image merupakan kombinasi dari istilah, simbol, tanda, nama, rancangan yang bermaksud mengenali barang atau jasa yang menjadi perbedaan dari pesaing. Brand image dikenal sebagai suatu hal penting yang menjadikan pertimbangan individu dalam menggunakan suatu barang atau jasa. Brand image membawa pengaruh penting pada adoption intention fintech dan memainkan peran positif dalam mempromosikan pencapaian pengguna untuk tujuan yang dimaksudkan. Brand image yang memiliki pengaruh penting pada persepsi pengguna tentang kualitas, nilai dan kepuasan mereka. Apabila pengguna merasa mengadopsi fintech tidak perlu memperhatikan brand image, maka niat pengguna untuk mengadopsi fintech akan rendah karena pengguna tidak memiliki gambaran atas citra merek fintech yang akan digunakan. Berdasarkan penelitian Krisnawati dan Ketut (2019) mengemukakan kalau brand image membawa pengaruh positif dan signifikan terhadap adoption intention fintech. Penelitian tersebut diperkuat oleh beberapa penelitian lain yang dikaji oleh Hu et al. (2019) dan Jin et al. (2020). Namun pada penelitian Indrawati dan Pattinama (2021) menyatakan brand image tidak signifikan terhadap adoption intention fintech. Dengan demikian hipotesis yang diusulkan adalah:

H1: Brand Image memiliki hubungan signifikan positif terhadap Adoption Intention Fintech.

\section{Trust}

Trust diartikan sebagai keyakinan atau kepercayaan bahwa fintech yang digunakan aman dan dapat dipercaya (Nguyen et al., 2016). Kepercayaan merupakan elemen penting yang mempengaruhi individu untuk mengadopsi fintech (Meyliana et al., 2019). Awalnya seseorang yang mulai menggunakan suatu barang atau jasa pastinya didasarkan dengan kepercayaan terhadap barang atau jasa yang digunakan. Maka itu sangat penting untuk mendapatkan kepercayaan seseorang yang kemudian akan mempengaruhi keputusan untuk mengadopsi fintech. Pada segi trust akan membawa pengaruh langsung atas rasa percaya yang ada pada diri seseorang mengenai perasaan atas kenyamanan dalam layanan yang digunakan. Apabila pengguna merasa mengadopsi fintech tidak perlu memperhatikan trust, maka niat pengguna untuk mengadopsi fintech akan rendah karena tidak memiliki dasar atas kepercayaan untuk menggunakan fintech. Trust dinyatakan terdapat pengaruh positif dan signifikan terhadap adoption intention fintech pada penelitian Nguyen et al. (2016), Ahmad et al. (2016), Fernando et al. (2018), Ma et al. (2018), Wong dan Mo (2019), Meyliana et al. (2019), Gupta et al. (2019), Nangin et al. (2020), Candra et al. (2020) dan Abebe dan Lessa (2020). Trust juga memiliki pengaruh tidak signifikan yang dikaji oleh Yuniarti (2020) dan Anjelina (2018). Dengan demikian hipotesis yang diusulkan adalah:

H2: Trust memiliki hubungan signifikan positif terhadap Adoption Intention Fintech. 


\section{Security}

Lai (2016) menjelaskan keamanan merupakan tingkat keandalan, keselamatan, privasi dan juga mengurangi risiko dalam mengadopsi suatu teknologi. Banyaknya individu yang khawatir terkait keamanan saat mengadopsi fintech. Permasalahan mengenai keamanan merupakan penghalang dalam mengadopsi fintech (Aydin \& Burnaz, 2016). Lai (2016) menyebutkan security mencakup tiga dimensi, yaitu keandalan, keamanan, dan privasi. Keamanan sangat penting dalam menentukan keputusan individu untuk mengadopsi fintech. Security merupakan suatu keamanan yang akan dirasakan para pengguna. Apabila pengguna merasa mengadopsi fintech tidak perlu memperhatikan security, maka niat pengguna untuk mengadopsi fintech akan rendah karena pengguna merasa tidak memiliki keamanan untuk menggunakan fintech. Aydin dan Burnaz (2016), Lai (2016), Ryu (2018), Teng et al. (2018), Wong dan Mo (2019), Putritama (2019), Hu et al. (2019), Chong et al. (2019), Ibrahim et al. (2019), Nangin et al. (2020), Nanggala (2020), dan Abebe dan Lessa (2020) menyatakan security memiliki hubungan signifikan positif terhadap adoption intention fintech. Terdapat pandangan lain yang menyatakan security tidak membawa pengaruh langsung terhadap adoption intention fintech yang dikaji oleh Jin et al. (2020) dan Luna et al. (2019). Dengan demikian hipotesis yang diusulkan adalah: H3: Security memiliki hubungan signifikan positif terhadap Adoption Intention Fintech.

\section{Perceived Usefulness}

Perceived usefulness merupakan tingkat kepercayaan dimana pengguna sistem tertentu mampu meningkatkan kinerja pengguna (Chong et al., 2019). Perceived Usefulness pada penggunaan fintech merujuk pada sejauh mana manfaat dan kesederhanaan dalam penggunaan. Jika pengguna merasa mengadopsi fintech tidak membawakan manfaat dan kesederhanaan, maka niat pengguna untuk mengadopsi fintech akan rendah. Perceived usefulness memiliki hubungan signifkan positif terhadap adaption intention fintech yang dikaji oleh Nguyen et al. (2016), Ahmad et al. (2016), Lai (2016), Fernando et al. (2018), Teng et al. (2018), Luna et al. (2019), Wong dan Mo (2019), Meyliana et al. (2019), Gupta et al. (2019), Putritama (2019), Hu et al. (2019), Chong et al. (2019), Jin et al. (2020) dan Abebe dan Lessa (2020). Namun pada beberapa penelitian lain yang dikaji oleh Candra et al. (2020), Ma et al. (2018) dan Dastan dan Gurler (2016). Dengan demikian hipotesis yang diusulkan adalah:

H4: Perceived Usefulness memiliki hubungan signifikan positif terhadap Adoption Intention Fintech.

\section{Perceived Ease of Use}

Perceived ease of use dikenal sebagai pengukuran atas tingkat kepercayaan individu dalam memakai sistem tertentu akan meringankan usaha untuk melakukan sesuatu (Ma et al., 2018). Jika pengguna merasa sistem tertentu sulit digunakan, maka niat untuk mengadopsi fintech akan rendah karena butuh usaha lebih untuk mempelajarinya.

Perceived ease of use dikenal sebagai pandangan individu atas kemudahan yang dirasakan dalam proses menggunakannya sehingga percaya bahwa transaksi online melalui mobile banking akan mudah. Proses menggunakan akan merasa adanya kemudahan karena hal tersebut penting dalam menjelaskan niat dan perilaku pengguna terhadap penggunaan teknologi baru (Chong et al., 2019). Persepsi kemudahan penggunaan diartikan sebagai mudah dipelajari dan digunakan untuk mencegah masalah penggunaan teknologi dalam transaksi keuangan. Perceived ease of use berhubungan positif dan signifikan terhadap adoption intention fintech yang selaras pada penelitian Nguyen et al. (2016), Ahmad et 
al. (2016), Lai (2016), Fernando et al. (2018), Ryu (2018), Ma et al. (2018), Luna et al. (2019), Wong dan Mo (2019), Meyliana et al. (2019), Gupta et al. (2019), Putritama (2019), Hu et al. (2019), Chong et al. (2019), Nangin et al. (2020), Abebe dan Lessa (2020) dan Candra et al. (2020). Pandangan lain yang dikaji oleh Teng et al. (2018), Ibrahim et al. (2019), Nanggala (2020), Jin et al. (2020) dan Dastan dan Gurler (2016) menyatakan perceived ease of use tidak membawa pengaruh langsung terhadap adoption intention fintech. Dengan demikian hipotesis yang diusulkan adalah:

H5: Perceived Ease of Use memiliki hubungan signifikan positif terhadap Adoption Intention Fintech.

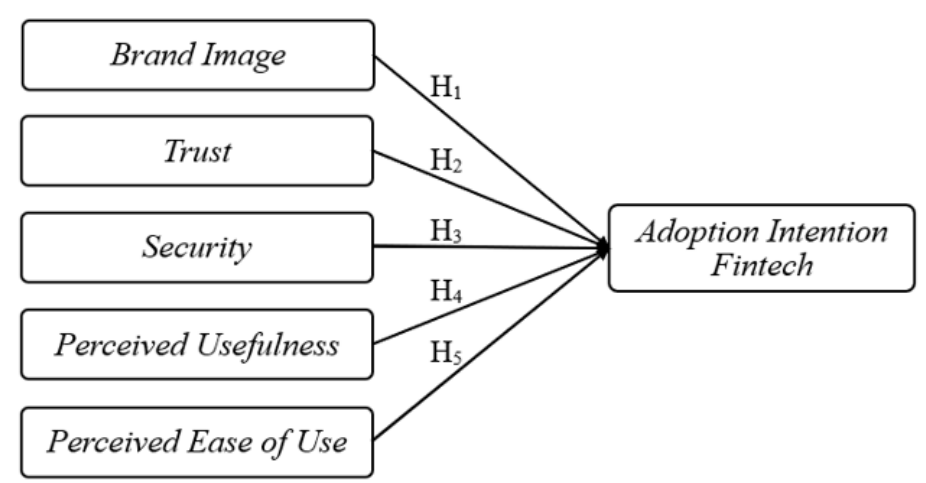

Gambar 2. Model Penelitian.

\section{METODOLOGI PENELITIAN Populasi dan Sampel}

Tujuan dari penelitian yang dilakukan guna menganalisis pengaruh brand image, trust, security, perceived usefulness, perceived ease of use terhadap adoption intention fintech di Kota Batam. Maka dari hal tersebut, masyarakat Kota Batam yang pernah menggunakan layanan fintech untuk melakukan pembayaran menjadi populasi dari penelitian yang dilakukan.

Adapun sampel yang diambil memafaatkan rumusan Hair et al. (2010) dengan asumsi n $\mathrm{x}$ 5, yang kemudian jumlah sampel sebanyak 150 dan data yang terkumpul dan dipakai sebanyak 150. Penelitian difokuskan pada pengguna layanan fintech seperti Dana, OVO, Go-Pay, Shopee Pay, Link Aja, iSaku, Ayopop, Doku, Sakuku, dan Paytren yang ada di mall. Penelitian ini dijalankan pada lokasi mall-mall Batam yang terdiri dari mall Grand Batam, BCS, dan Nagoya Hill. Pengelompokan demografi responden diringkas pada tabel 2. 
Tabel 2. Statistik Demografi Responden

\begin{tabular}{lrr}
\hline & Jumlah & Persentase (\%) \\
\hline Jenis Kelamin & & \\
Laki-Laki & 65 & $43,3 \%$ \\
Perempuan & 85 & $56,7 \%$ \\
Usia & & \\
17-25tahun & 97 & $64,7 \%$ \\
26-35tahun & 37 & $24,7 \%$ \\
36-45tahun & 13 & $8,7 \%$ \\
46-55tahun & 3 & $2,0 \%$ \\
55tahun & 0 & $0,0 \%$ \\
Pendidikan & & \\
SMA/SMK & 30 & $20,0 \%$ \\
Diploma & 16 & $10,7 \%$ \\
Sarjana & 97 & $64,7 \%$ \\
Magister & 7 & $4,7 \%$ \\
Pekerjaan & & \\
Pelajar / Mahasiswa & 44 & $29,3 \%$ \\
Wiraswasta & 75 & $50,0 \%$ \\
Karyawan Swasta & 31 & $20,7 \%$ \\
Tidak Bekerja & 0 & $0,0 \%$
\end{tabular}

Sumber: Pengolahan data (2021)

Melalui penelitian yang dilakukan dengan penyebaran angket kepada responden. Angket berisi 30 pertanyaan mengenai variabel yang diteliti dan kemudian terkumpulnya hasil data akan diolah memanfaatkan program SPSS. Proses pengumpulan data yang dilakukan melalui penelitian yang dilakukan memakai metode pembagian kuesioner kepada calon responden melalui scan QR code yang kemudian dialihkan ke halaman google form, atau melalui survei dengan menyebarkan langsung kuesioner kepada setiap calon responden. Metode penelitian kuantitatif yang disampaikan Sugiyono (2016) ialah metode penelitian yang dipakai, bertujuan untuk menganalisis data yang dikumpulkan dari populasi atau sampel tertentu secara statistik dalam tujuannya melakukan uji hipotesis yang sudah ditentukan.

\section{HASIL PENELITIAN}

Pada penelitian ini, uji validitas yang dilakukan menggunakan SPSS dinyatakan semua pertanyaan valid dengan memiliki nilai validasi >0,6 (Wibowo, 2012). 
Tabel 3. Hasil Uji Validitas

\begin{tabular}{lcc}
\hline \multicolumn{1}{c}{ Pernyataan } & $\begin{array}{c}\text { Pearson } \\
\text { Correlation }\end{array}$ & Kesimpulan \\
\hline Brand Image 1 & 0,888 & Valid \\
Brand Image 2 & 0,710 & Valid \\
Brand Image 3 & 0,862 & Valid \\
Brand Image 4 & 0,768 & Valid \\
Trust 1 & 0,861 & Valid \\
Trust 2 & 0,880 & Valid \\
Trust 3 & 0,899 & Valid \\
Trust 4 & 0,900 & Valid \\
Trust 5 & 0,857 & Valid \\
Security 1 & 0,905 & Valid \\
Security 2 & 0,888 & Valid \\
Security 3 & 0,826 & Valid \\
Security 4 & 0,867 & Valid \\
Perceived Usefulness 1 & 0,842 & Valid \\
Perceived Usefulness 2 & 0,806 & Valid \\
Perceived Usefulness 3 & 0,823 & Valid \\
Perceived Usefulness 4 & 0,835 & Valid \\
Perceived Usefulness 5 & 0,840 & Valid \\
Perceived Usefulness 6 & 0,643 & Valid
\end{tabular}

Sumber: Pengolahan data (2021)

Pada tahap selanjutnya, uji reliabilitas dijalankan dengan memanfaatkan uji Cronbach's Alpha. Pada tabel 4, hasil uji menyatakan semua variabel penelitian reliabel dikarenakan memiliki nilai >0,6 (Wibowo, 2012).

Tabel 4. Hasil Uji Reliabilitas

\begin{tabular}{lcc}
\hline \multicolumn{1}{c}{ Variabel } & $\begin{array}{c}\text { Cronbach's } \\
\text { Alpha }\end{array}$ & Kesimpulan \\
\hline Brand Image & 0,821 & Reliabel \\
Trust & 0,926 & Reliabel \\
Security & 0,895 & Reliabel \\
Perceived Usefulness & 0,892 & Reliabel \\
Perceived Ease of Use & 0,934 & Reliabel \\
Adoption Intention & 0,880 & Reliabel \\
\hline
\end{tabular}

Sumber: Pengolahan data (2021)

Pengujian normalitas dijalankan melalui p-plot. Data dapat dinyatakan normal bilamana data menyebar di sekitar garis diagonal dan mengikuti arah garis diagonal (Ghozali, 2018). Pada gambar 3, persebaran titik-titik mengikuti dan mendekati garis diagonal sehingga data diambil kesimpulan berdistribusi normal. 


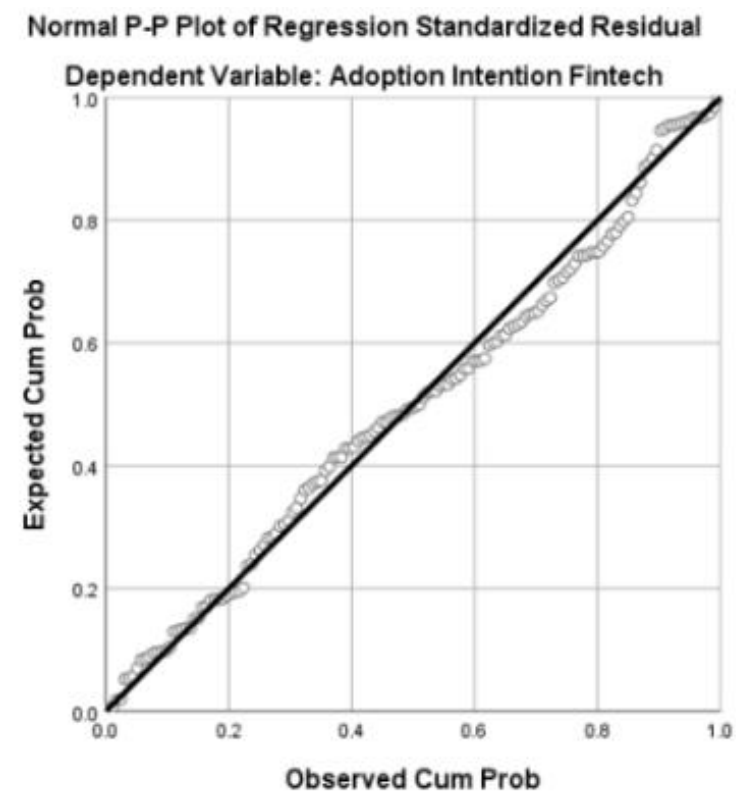

Sumber: Pengolahan data (2021)

Gambar 3. Hasil Uji P-Plot

Selain melalui pengujian p-plot terdapat pengujian lain dalam menguji tingkat kenormalan suatu data. Uji tersebut disebut sebagai uji test of normality kolmogorovsmirnov, nilai signifikan $>0,05$ maka bisa diambil kesimpulan bahwa hasil penelitian ini normal (Ghozali, 2018). Hasil penelitian pada tabel 5 dinyatakan normal karena sudah memenuhi kriteria yang ada.

\begin{tabular}{lc} 
Tabel 5. Hasil Uji Kolmogorov-Smirnov \\
\hline $\begin{array}{l}\text { Unstandardized } \\
\text { Residual }\end{array}$ & Kesimpulan \\
\hline 0,200 & Normal \\
\hline
\end{tabular}

Sumber: Pengolahan data (2021)

Variabel dinyatakan tidak terjadi atau bebas multikolinearitas di mana nilai tolerance value $>0,10$ dan VIF <10 (Ghozali, 2018). Hasil pengujian menunjukkan bebas multikolinearitas pada variabel brand image, trust, security, perceived usefulness, dan perceived ease of use.

Tabel 6. Hasil Uji Multikolinearitas

\begin{tabular}{|c|c|c|c|}
\hline Variabel & Tolerance & $V I F$ & Kesimpulan \\
\hline $\begin{array}{l}\text { Brand } \\
\text { Image }\end{array}$ & 0,147 & 6,793 & $\begin{array}{l}\text { Bebas } \\
\text { Multikolinearitas }\end{array}$ \\
\hline Trust & 0,102 & 9,810 & $\begin{array}{l}\text { Bebas } \\
\text { Multikolinearitas }\end{array}$ \\
\hline Security & 0,193 & 5,180 & $\begin{array}{l}\text { Bebas } \\
\text { Multikolinearitas }\end{array}$ \\
\hline $\begin{array}{l}\text { Perceived } \\
\text { Usefulness }\end{array}$ & 0,181 & 5,523 & $\begin{array}{l}\text { Bebas } \\
\text { Multikolinearitas }\end{array}$ \\
\hline $\begin{array}{l}\text { Perceived } \\
\text { Ease of } \\
\text { Use }\end{array}$ & 0,173 & 5,782 & $\begin{array}{l}\text { Bebas } \\
\text { Multikolinearitas }\end{array}$ \\
\hline
\end{tabular}


Sumber: Pengolahan data (2021)

Glejser berfungsi untuk menguji heteroskedastisitas. Hasil dapat dinyatakan tidak terjadi heteroskedastisitas apabila hasil signifikan lebih besar dari 0,05 (Wibowo, 2012). Tabel 7 menunjukkan hasil bahwa brand image, trust, security, perceived usefulness, dan perceived ease of use bebas dari gejala heteroskedastisitas.

Tabel 7. Hasil Uji Heteroskedastisitas

\begin{tabular}{lcc}
\hline \multicolumn{1}{c}{ Variabel } & Sig. & Keterangan \\
\hline Brand Image & 0,924 & $\begin{array}{l}\text { Bebas dari gejala } \\
\text { heteroskedastisitas } \\
\text { Trust }\end{array}$ \\
Security & 0,203 & $\begin{array}{l}\text { Bebas dari gejala } \\
\text { heteroskedastisitas } \\
\text { Bebas dari gejala } \\
\text { heteroskedastisitas } \\
\text { Bebas dari gejala } \\
\text { heteroskedastisitas }\end{array}$ \\
Perceived Ease of Use & 0,738 & $\begin{array}{l}\text { Bebas dari gejala } \\
\text { heteroskedastisitas }\end{array}$ \\
\hline
\end{tabular}

Sumber: Pengolahan data (2021)

Variabel independen dinyatakan berkorelasi signifikan terhadap variabel dependen apabila memiliki nilai signifikansi $<0,05$, sebaliknya jika $>0,05$ dinyatakan tidak berpengaruh signifikan (Ghozali, 2018). Sesuai tabel 8, hasil pengujian memiliki nilai signifikansi sebesar 0,000 atau <0,05. Maka dari hal tersebut bisa diambil kesimpulan brand image, trust, security, perceived usefulness dan perceived ease of use secara simultan memberikan pengaruh signifikan terhadap adoption intention.

Tabel 8. Hasil Uji F

\begin{tabular}{ccc}
\hline Model & F & Sig. \\
\hline Regression Residual & 176,046 & 0,00 \\
\hline
\end{tabular}

Sumber: Pengolahan data (2021)

Uji t bertujuan mengklarifikasi pengaruh tiap-tiap variabel independen secara parsial. Pengukuran berdasarkan nilai signifikansi $<0,05$ yang berarti variabel independen memberikan pengaruh variabel dependen dan $>0,05$ dinyatakan tidak mempengaruhi variabel dependen (Ghozali, 2018).

Hipotesis pertama ditolak, dikarenakan hasil penelitian memiliki nilai uji t sebesar 0,529 dan nilai signifikansi sebesar 0,597 yang di mana menyatakan brand image tidak berpengaruh signifikan terhadap niat adopsi fintech di Kota Batam. Melalui penelitian didapati hasil selaras dengan yang dikaji oleh Indrawati dan Pattinama (2021) yang mengemukakan brand image tidak memiliki pengaruh penting pada niat adopsi fintech.

Trust tidak berhubungan signifikan terhadap niat adopsi fintech di Kota Batam dikarenakan memiliki nilai uji t sebesar 0,418 dan nilai signifikansi 0,677. Sehingga hipotesis kedua ditolak, namun melalui penelitian didapati hasil selaras dengan yang dikaji oleh Yuniarti (2020) \& Anjelina (2018).

Security memiliki nilai uji t sebesar 3,809 dan nilai signifikansi 0,000 yang menyatakan memberikan pengaruh positif dan signifikan terhadap niat adopsi fintech di Kota Batam. Melalui penelitian didapati hasil menunjukkan hipotesis ketiga diterima. Melalui penelitian didapati hasil selaras dengan penelitian yang dikaji oleh Aydin dan Burnaz 
(2016) Lai (2016), Ryu (2018), Teng et al. (2018), Wong dan Mo (2019), Putritama (2019), Hu et al. (2019), Chong et al. (2019), Ibrahim et al. (2019), Nangin et al. (2020), Nanggala (2020), dan Abebe dan Lessa (2020).

Perceived Usefulness memiliki nilai uji t sebesar 3,331 dan nilai signifikansi 0,001 yang menyatakan manfaat penggunaan memiliki hubungan signifikan positif terhadap niat adopsi fintech di Kota Batam. Sehingga hipotesis keempat dibuktikan dapat diterima. Hasil penelitian ini didukung dengan artikel Ahmad et al. (2016), Lai (2016), Fernando et al. (2018), Ryu (2018), Teng et al. (2018), Luna et al. (2019), Wong dan Mo (2019), Meyliana et al. (2019), Gupta et al. (2019), Putritama (2019), Hu et al. (2019), Chong et al. (2019), Ibrahim et al. (2019), Nangin et al. (2020), dan Abebe dan Lessa (2020).

Perceived Ease of Use memiliki nilai uji t sebesar 5,124 dan nilai signifikansi 0,000 yang menyatakan memiliki signifikan positif terhadap niat adopsi fintech di Kota Batam, sehingga hipotesis kelima di terima. Melalui penelitian didapati hasil selaras dengan artikel penelitian Nguyen et al. (2016), Ahmad et al. (2016), Lai (2016), Fernando et al. (2018), Ryu (2018), Ma et al. (2018), Luna et al. (2019), Wong dan Mo (2019), Meyliana et al. (2019), Gupta et al. (2019), Putritama (2019), Hu et al. (2019), Chong et al. (2019), Nangin et al. (2020), Abebe dan Lessa (2020) dan Candra et al. (2020).

Tabel 9. Hasil Uji t

\begin{tabular}{lccl}
\hline \multicolumn{1}{c}{ Variabel } & $\mathbf{t}$ & Sig. & Keterangan \\
\hline Brand Image & 0,529 & 0,597 & $\begin{array}{l}\text { Hipotesis } \\
\text { Ditolak } \\
\text { Trust }\end{array}$ \\
Security & 0,418 & 0,677 & $\begin{array}{l}\text { Hipotesis } \\
\text { Ditolak }\end{array}$ \\
Perceived Usefulness & 3,331 & 0,001 & $\begin{array}{l}\text { Hipotesis } \\
\text { Diterima } \\
\text { Diterima }\end{array}$ \\
Perceived Ease of Use & 5,124 & 0,000 & $\begin{array}{l}\text { Hipotesis } \\
\text { Diterima }\end{array}$ \\
\hline
\end{tabular}

Sumber: Pengolahan data (2021)

Berdasarkan hasil pengujian, terlihat bahwa nilai Adjusted $R$ Square sebesar 0,855 atau 85,5\%. Yang berarti security, perceived usefulness, dan perceived ease of use mempengaruhi niat adopsi sebesar $85,5 \%$ dan $14,5 \%$ dipengaruhi aspek lain yang tidak dijelaskan pada model.

Tabel 10. Hasil Uji t

\begin{tabular}{ccc}
\hline $\mathbf{R}$ & $\boldsymbol{R}$ Square & Adjusted $\boldsymbol{R}$ Square \\
\hline 0,927 & 0,859 & 0,855 \\
\hline
\end{tabular}

Sumber: Pengolahan data (2021)

\section{KESIMPULAN}

Melalui proses uji data dengan sebanyak 150 responden terhadap Adoption Intention Fintech di Kota Batam, dapat disimpulkan:

1. Brand image tidak memberikan pengaruh signifikan terhadap niat adopsi fintech di Kota Batam.

2. Trust tidak memberikan pengaruh signifikan terhadap niat adopsi fintech di Kota Batam.

3. Security memberikan pengaruh signifikan positif terhadap niat adopsi fintech di Kota Batam.

4. Perceived Usefulness memberikan pengaruh signifikan positif terhadap niat adopsi fintech di Kota Batam. 
5. Perceived Ease of Use memberikan pengaruh signifikan positif terhadap niat adopsi fintech di Kota Batam..

\section{UCAPAN TERIMA KASIH}

Terimakasih saya ucapkan tertuju kepada Bapak Dr. Iskandar selaku Rektor Universitas Internasional Batam, Ibu Dr. Meliana, Bapak Dr. Teddy Jurnali dan Bapak Dr. Hepy Hefri Ariyanto selaku Wakil Rektor Universitas Int ernasional Batam, Ibu Dr. Evi Silvana Muchsinati selaku Ketua Prodi Manajemen Fakultas Ekonomi Universitas Internasional Batam, Dr. Yandi Suprapto, S.E., M.M. selaku dosen pembimbing, serta para dosen, staf perpustakaan, keluarga, dan teman-teman penulis yang telah memberi bantuan, semangat, dan saran dalam penyusunan artikel ini.

\section{DAFTAR PUSTAKA}

Abebe, F., \& Lessa, L. (2020). Factors affecting mobile payment adoption by merchants in Ethiopia. African Conference on Information Systems and Technology Journal, 2(2), $1-11$.

Ahmad, H., Ismail, Y. B., Shamsudin, B., \& Kadir, B. Bin. (2016). Review of customer adoption on mobile payment. Journal of Postgraduate Current Business Research, 1(2), $8-14$.

Anjelina, A. (2018). Persepsi Konsumen Pada Penggunaan E-Money. Journal of Applied Managerial Accounting, 2(2), 219-231. https://doi.org/10.30871/jama.v2i2.934

Aydin, G., \& Burnaz, S. (2016). Adoption of mobile payment systems: a study on mobile wallets. Journal of Business Economica and Finance, 5(1), 73-73. https://doi.org/10.17261/pressacademia.2016116555

Bappenas. (2019). Jumlah Penduduk Indonesia 2019 Mencapai 267 Juta Jiwa. Katadata.Co.Id.https://databoks.katadata.co.id/datapublish/2019/01/04/jumlahpenduduk -indonesia-2019-mencapai-267-juta-jiwa

Belanche, D., Casaló, L. V., \& Flavián, C. (2019). Artificial intelligence in fintech: Understanding robo-advisors adoption among customers. Industrial Management and Data Systems, 119(7), 1411-1430. https://doi.org/10.1108/IMDS-08-2018-0368

Candra, S., Nuruttarwiyah, F., \& Hapsari, I. H. (2020). Revisited the technology acceptance model with e-trust for peer-to-peer lending in Indonesia (perspective from fintech users). International Journal of Technology, 11(4), 710-721. https://doi.org/10.14716/ijtech.v11i4.4032

Chong, T. P., Choo, K. S. W., San, Y. Y., Chan, P. Y., Teh, H. L. J., \& Ng, S. S. (2019). An adoption of fintech service in Malaysia. South East Asia Journal of Contemporary Business, Economics and Law, 18(5), 73-92.

Dastan, I., \& Gurler, C. (2016). Factors affecting the adoption of mobile payment systems: An empirical analysis. Emerging Markets Journal, 6(1), 1-16. https://doi.org/10.5195/emaj.2016.92 
Davis, F. D., Bagozzi, R. P., \& Warshaw, P. R. (1989). User Acceptance of Computer Technology: A Comparison of Two Theoretical Models. Management Science, 35(8), 982-1003. https://doi.org/10.1287/mnsc.35.8.982

Fernando, E., Surjandy, Meyliana, \& Touriano, D. (2018). Development and validation of instruments adoption fintech services in indonesia (perspective of trust and risk). $3 \mathrm{rd}$ International Conference on Sustainable Information Engineering and Technology Journal, 2(1), 283-287. https://doi.org/10.1109/SIET.2018.8693192

Ghozali, I. (2018). Aplikasi Analisis Multivariate dengan Program IBM SPSS 25 (A. Tejokusuma (ed.); Edisi 9). Universitas Diponegoro.

Gupta, M. A., Tyagi, D. A., \& Rai, D. K. (2019). Adoption of mobile wallet: An empirical study among generation Y. Journal of The Gujarat Research Society, 21(11), 31-38.

Hair, Beckett, C., Eriksson, L., Johansson, E., \& Wikström, C. (2010). Multivariate Data Analysis (MVDA). In Pharmaceutical Quality by Design: A Practical Approach. https://doi.org/10.1002/9781118895238.ch8

Haluan, N. (2019). Kemendagri Minta Daerah Terapkan Transaksi Non Tunai.

Hu, Z., Ding, S., Li, S., Chen, L., \& Yang, S. (2019). Adoption intention of fintech services for bank users: An empirical examination with an extended technology acceptance model. Journal of Symmetry, 11(3), 1-16. https://doi.org/10.3390/sym11030340

Ibrahim, M. H., Hussin, S. R., \& Hussin, S. H. (2019). Factors influencing Malaysian consumers' intention to use quick response (QR) mobile payment. Jurnal Pengurusan, 57. https://doi.org/10.17576/pengurusan-2019-57-02

Indrawati, L., \& Pattinama, M. M. (2021). Brand Image, Kualitas Pelayanan Dan Kepuasan Konsumen Di Dalam Pengaruhnya Terhadap Minat Ulang Penggunaan Aplikasi Dana. Jurnal Bisnis Dan Manajemen, 8(1), 16-21.

Jin, C. C., Seong, L. C., \& Khin, A. A. (2020). Consumers' behavioural intention to accept of the mobile wallet in Malaysia. Journal of Southwest Jiaotong University, 55(1), 1-13. https://doi.org/10.35741/issn.0258-2724.55.1.3

Krisnawati, N. W., \& Ketut, W. (2019). Peran brand image memediasi pengaruh E-wom terhadap niat konsumen menggunakan ovo mobile payment. Jurnal Manajemen, 9(2), 79-98. https://doi.org/10.1002/9781118785317.weom090353

Kurniawan, I. (2019). Prediksi Perkembangan Industri Startup Indonesia setelah 2020. Entrepreneur UAI. https://entrepreneur.uai.ac.id/prediksi-perkembangan-industristartup-indonesia-setelah-2020/

Lai, P. C. (2016). Design and Security impact on consumers' intention to use single platform E-payment. Interdisciplinary Information Sciences, 22(1), 111-122. https://doi.org/10.4036/iis.2016.r.05 
Lai, P. C. (2018). Security as an extension to tam model: Consumers' intention to use a single platform e-payment. Asia-Pacific Journal of Management Research and Innovation, 13(3-4), 110-119. https://doi.org/10.1177/2319510x18776405

Lee, I. (2017). E-Business Development and Management in the Global Economy.

Lu, X., \& Lu, H. (2020). Understanding chinese millennials' adoption intention towards third-party mobile payment. Information Resources Management Journal, 33(2), 40-63. https://doi.org/10.4018/IRMJ.2020040103

Luna, I. R. De, Cabanillas, F. L., Fernandez, J. S., \& Leiva, F. M. (2018). Mobile payment is not all the same: The adoption of mobile payment systems depending on the technology applied. Technological Forecasting and Social Change, 4(1), 931-944. https://doi.org/10.1016/j.techfore.2018.09.018

Luna, I. R. de, Cabanillas, F. L., Juan, S.-F., \& Leiva, F. M. (2018). Mobile payment is not all the same: The adoption of mobile payment systems depending on the technology applied. Technological Forecasting and Social Change, 146(August), 931-944. https://doi.org/10.1016/j.techfore.2018.09.018

Ma, L., Su, X., Yu, Y., Wang, C., Lin, K., \& Lin, M. (2018). What drives the use of mpayment? An empirical study about alipay and wechat payment. International Conference on Service Systems and Service Management Journal, 1(1), 1-6. https://doi.org/10.1109/ICSSSM.2018.8465029

Malik, A. (2020). Transaksi Uang Elektronik Agustus Melesat Tembus Rp17,23 Triliun, Ini Data Historisnya. Bareksa. https://www.bareksa.com/berita/berita-ekonomiterkini/2020-10-13/transaksi-uang-elektronik-agustus-melesat-tembus-rp1723-triliunini-data-historisnya

Meyliana, M., Fernando, E., \& Surjandy, S. (2019). The Influence of Perceived Risk and Trust in Adoption of FinTech Services in Indonesia. CommIT (Communication and Information Technology) Journal, 31. https://doi.org/10.21512/commit.v13i1.5708

Morosan, C., \& DeFranco, A. (2016). It's about time: Revisiting UTAUT2 to examine consumers' intentions to use NFC mobile payments in hotels. International Journal of Hospitality Management, 53(16), 17-29. https://doi.org/10.1016/j.ijhm.2015.11.003

Nanggala, A. Y. A. (2020). Use of fintech for payment: Approach to technology acceptance model modified. Journal of Contemporary Information Technology, Management, and Accounting, 1(1), 1-8.

Nangin, M. A., Barus, I. R. G., \& Wahyoedi, S. (2020). The effects of perceived ease of use, security, and promotion on trust and its implications on fintech adoption. Journal of Consumer Sciences, 5(2), 124-138. https://doi.org/10.29244/jcs.5.2.124-138

Nguyen, T. N., Cao, T. K., Dang, P. L., \& Nguyen, H. A. (2016). Predicting consumer intention to use mobile payment services: empirical evidence from Vietnam. 
$\begin{array}{lllll}\text { International Journal of } & \text { Marketing } & \text { Studies, } & 8(1), & \end{array}$ https://doi.org/10.5539/ijms.v8n1p117

Parastiti, Mukhlis, \& Haryono. (2015). Analisis Penggunaan Uang Elektronik Pada Mahasiswa Fakultas Ekonomi Universitas Negeri Malang (Studi Kasus: Uang Elektronik Brizzi). Jurnal Ekonomi Dan Studi Pembangunan, 7(1), 75-82.

Putritama, A. (2019). The Mobile Payment Fintech Continuance Usage Intention in Indonesia. Jurnal Economia, 243-258. https://doi.org/10.21831/economia.v15i2.26403

Rahadian, L. (2019). Industri Pembayaran Digital : Bank dan Fintech Berebut Pasar?

Routray, S., Khurana, R., Payal, R., \& Gupta, R. (2019). A Move towards Cashless Economy: A Case of Continuous Usage of Mobile Wallets in India. Theoretical Economics Letters, 9(4), 1152-1166. https://doi.org/10.4236/tel.2019.94074

Ryu, H. S. (2018). Understanding benefit and risk framework of fintech adoption: comparison of early adopters and late adopters. Proceedings of the 51st Hawaii International Conference on System Sciences, 51(12), 3864-3873. https://doi.org/10.24251/hicss.2018.486

Sugiyono. (2016). Metode Penelitian Kuantitatif, Kualitatif, dan R\&D. Alfabeta, Bandung.

Teng, P. K., Heng, B. L. J., \& Abdullah, S. I. N. W. (2018). Distinctive comparison of consumers' mobile payment adoption between China and Malaysia. Asia Proceedings of Social Sciences, 2(3), 57-61. https://doi.org/10.31580/apss.v2i3.258

Wibowo, A. E. (2012). Aplikasi Praktis SPSS Dalam Penelitian (A. Djojo (ed.); kedua). Gava Media.

Wong, W. H., \& Mo, W. Y. (2019). A Study of Consumer Intention of Mobile Payment in Hong Kong, Based on Perceived Risk, Perceived Trust, Perceived Security and Technological Acceptance Model. Journal of Advanced Management Science, 7(2), 3338. https://doi.org/10.18178/joams.7.2.33-38

Yadav, P. (2020). Active determinants for adoption of mobile wallet. Authentic Assessment in Social Studies, 12(1), 85-95. https://doi.org/10.4324/9780429261114-6

Yuniarti, V. (2020). Faktor - Faktor Yang Memengaruhi Minat Penggunaan Financial Technology Peer To Peer Lending. Journal of Chemical Information and Modeling, 53(9), 1689-1699 